\title{
The Performance of a Sumerian Wedding Song (CT 58, 12)
}

\author{
by Sam Mirelman and Walther Sallaberger - München
}

A close examination of the Old Babylonian Sumerian song CT 58, 12, in terms of its graphic arrangement and its literary patterns, leads to a better understanding of its performance: male and female singers participate, soloists and choir alternate, and vocables feature prominently besides the Sumerian text. The song can be situated within the marriage ceremony.

\section{Introduction}

The Old Babylonian Sumerian text CT 58, 12 (BM 85206) is remarkable, firstly for the extensive use of 'unintelligibles' or 'vocables', secondly for its graphic arrangement and thirdly for the repeated indication ne šge- $\mathrm{yal}_{2}$. As the alternation between phrases in Emesal and the main dialect of Sumerian makes clear, we are dealing with a dialogue between male and female partners. The divine names locate the text in the context of the Inana-Dumuzi corpus of Sumerian literature.

The tablet BM 85206 is part of the 99-4-15 collection at the British Museum, which was acquired from the Paris dealer I. Elias Gejou, and thus its provenance cannot be determined (Sigrist e.a. 1996, ix and 248). The upper part of the tablet (width ca. $10.5 \mathrm{~cm}$, length ca. $11.5 \mathrm{~cm}$ ) is preserved, with perhaps half of it missing. The format of the tablet is unusual, since it is wider than the standard Old Babylonian imgida. Furthermore, its surface is not covered by a fine slip and is not carefully smoothed, as it normally appears with Old Babylonian literary and school texts. ${ }^{1}$ As Steve Tinney remarks (personal communication), this coarse finish may relate to the practical use of texts; furthermore, Tinney compares it to a Nippur group of hymns known in single exemplars, which may represent texts prepared for performance.

\footnotetext{
1 We thank Steve Tinney for these observations on the format of CT 58, 12, which are based on his intimate knowledge of the typology of Old Babylonian tablets.
} 


\section{Edition of CT 58, 12}

The text was copied by Alster, and some lines were transliterated in the preface (Alster/Geller 1990, 12). The greater part of the reverse was transliterated by Volk (1994, 189 note 71), who added some notes on the 'vocables'. A short description of the text as "Wechselgesang über Inanna und Ama'ušumgal'anna" was given by Fritz (2003, 157f.), and Shehata (2009, 357-360) discusses the text in the context of music in the Old Babylonian period.

The transliteration is based on a set of photographs and repeated collations of the original. The values for Sumerian are based on Attinger apud Mittermayer (2006).

In the transliteration below, various kinds of text are distinguished as follows:

- main dialect Sumerian is in Roman Type (e.g. nam-nin)

- Emesal dialect Sumerian is in bold type (e.g. mu-lu)

- vocables (see below) in italics (e.g. e-ia el-lu)

- the performative instruction $\mathrm{ne} \breve{\mathrm{s}}-\mathrm{ge}-\mathrm{gal}_{2}$ is underlined

Reading based on collations that deviate from the handcopy of $\mathrm{B}$. Alster are indicated by asterisks $(*)$.

Obv.

\begin{tabular}{|c|c|c|c|}
\hline $\begin{array}{l}1 \\
1 \mathrm{a}\end{array}$ & {$\left[\right.$ in]-r $\operatorname{nin}^{* \top}-\mathrm{e}^{*} \mathrm{suku}_{5}{ }^{*}$} & * nam-dub & $\begin{array}{l}u_{4} \text { an- }^{\top} \mathrm{ne}_{2}{ }^{* 1} \text { nam-nin } a \mathrm{mu}-{ }^{\top} \mathrm{x}(\mathrm{x})^{\top} \\
\text { yeš-ge--gal }\end{array}$ \\
\hline 2 & {$\left[\begin{array}{lll}e-i a & e l\end{array}\right]-l u^{*}$} & $a$ nam-nin ${ }^{\circ} *$ & nam-nin e-ia-am-ma-mu \\
\hline $2 \mathrm{a}$ & & neš*-ge* $\mathrm{yal}_{2}^{*}$ & \\
\hline 3 & {$[e-e]-i a^{*}-a^{\circ}\{\mathrm{A}\}^{*}$} & & $a-a-a$ \\
\hline $3 a$ & ${ }^{\circ}\{\mathrm{A}\}$ & & $\eta \mathrm{ge}-\mathrm{ge}-\eta \mathrm{al}_{2}$ \\
\hline
\end{tabular}

B 4 ' $\mathrm{ku}_{3}{ }^{* 1}$ dinana-ke ${ }^{*} \mathrm{suku}_{5}{ }^{*}$ nam-dub $u_{4} \mathrm{nam}-\mathrm{nin} e$ nam-nin $a$ 4a $\underline{\text { geš-ge-nal }}$

$5 \quad e-i a * e l-l u$

$6 \quad e-e-i a-a \quad a$ nam-nin ${ }^{\circ}$ nam-nin e-ia-am-ma-mu

7 mu-lu a-la-lu in-gur $\quad{ }^{\circ} \quad a-a-a$

7 a yeš-ge-gal

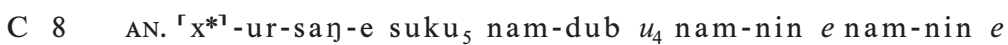
$8 \mathrm{a} \quad$ yeš-ge- ${ }^{\mathrm{r}} \mathrm{yal}_{2}{ }^{\top}$

$9 \quad$ e-ia el-lu

$10 e-[e]-i a^{*}-a \quad a$ nam-nin nam-nin ' $e-i a^{\top}-a m-m a-m u$

11 mu-lu a-la-lu in-gur* ${ }^{*} \ldots{ }^{\circ *} \quad a-a-a$

11a $\underline{\text { geš-ge- } \mathrm{gal}_{2}}$

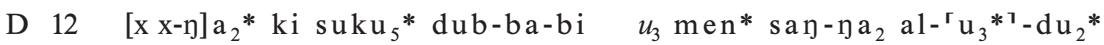
$12 \mathrm{a}$

ne š ${ }^{\top} \mathrm{ge}^{\top} \mathrm{nal}_{2}$ 


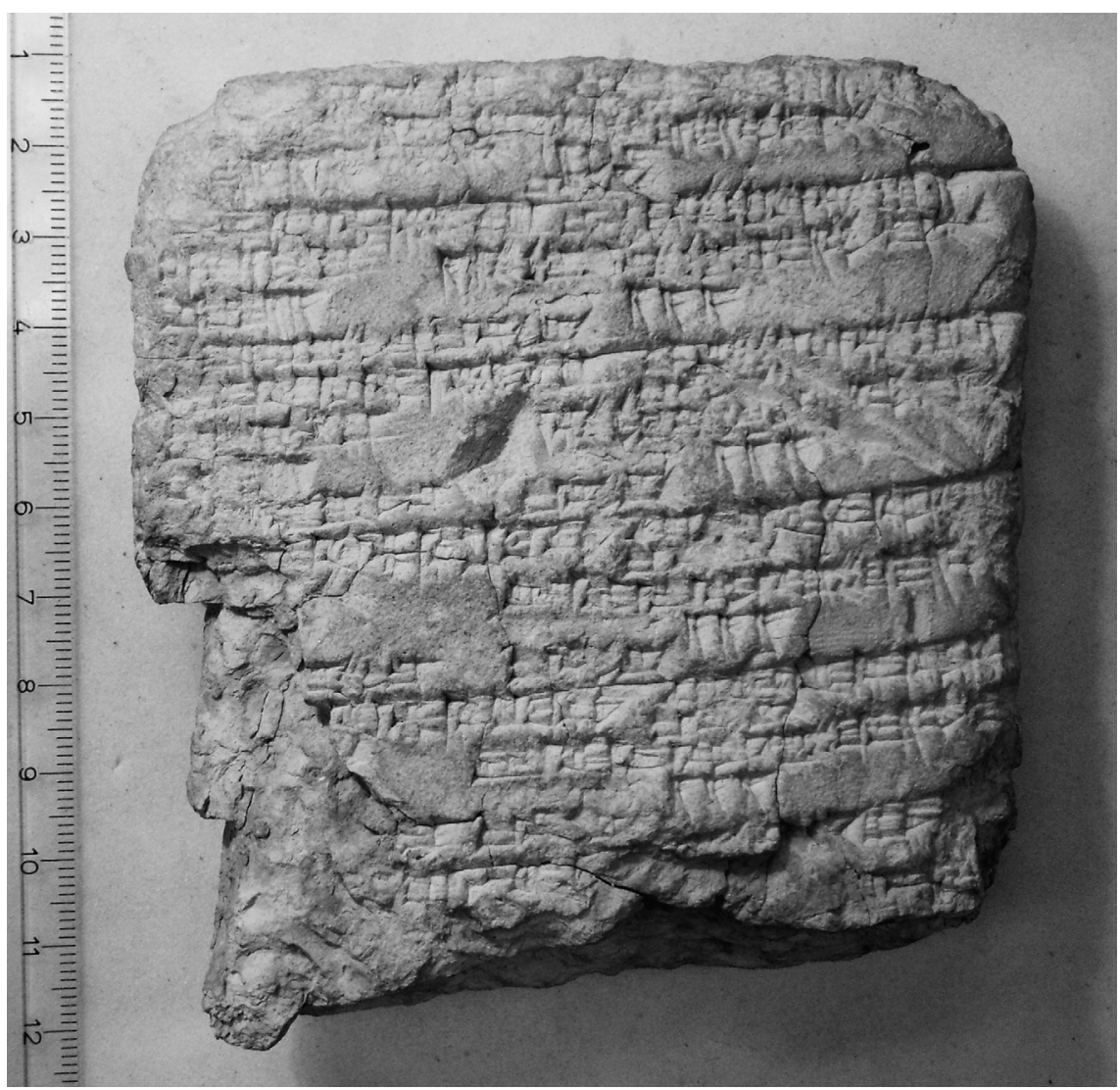

BM 85206, obv.

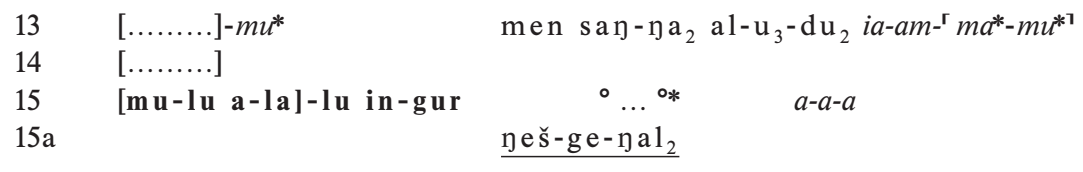

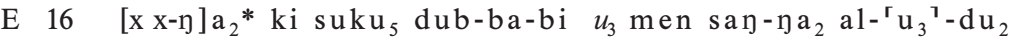

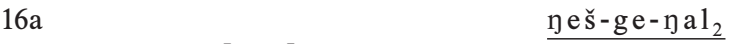

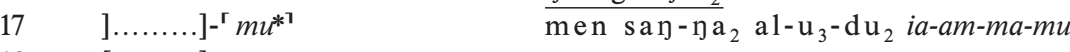 $18 \quad[\ldots \ldots . .$.
19 [mu-lu a-la-lu in]-gur $\quad{ }^{\circ}{ }^{\circ *} \quad a-a-a$ 19a $\underline{\text { ge š-ge-gal }}$

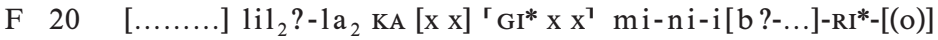

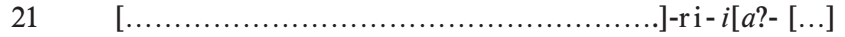




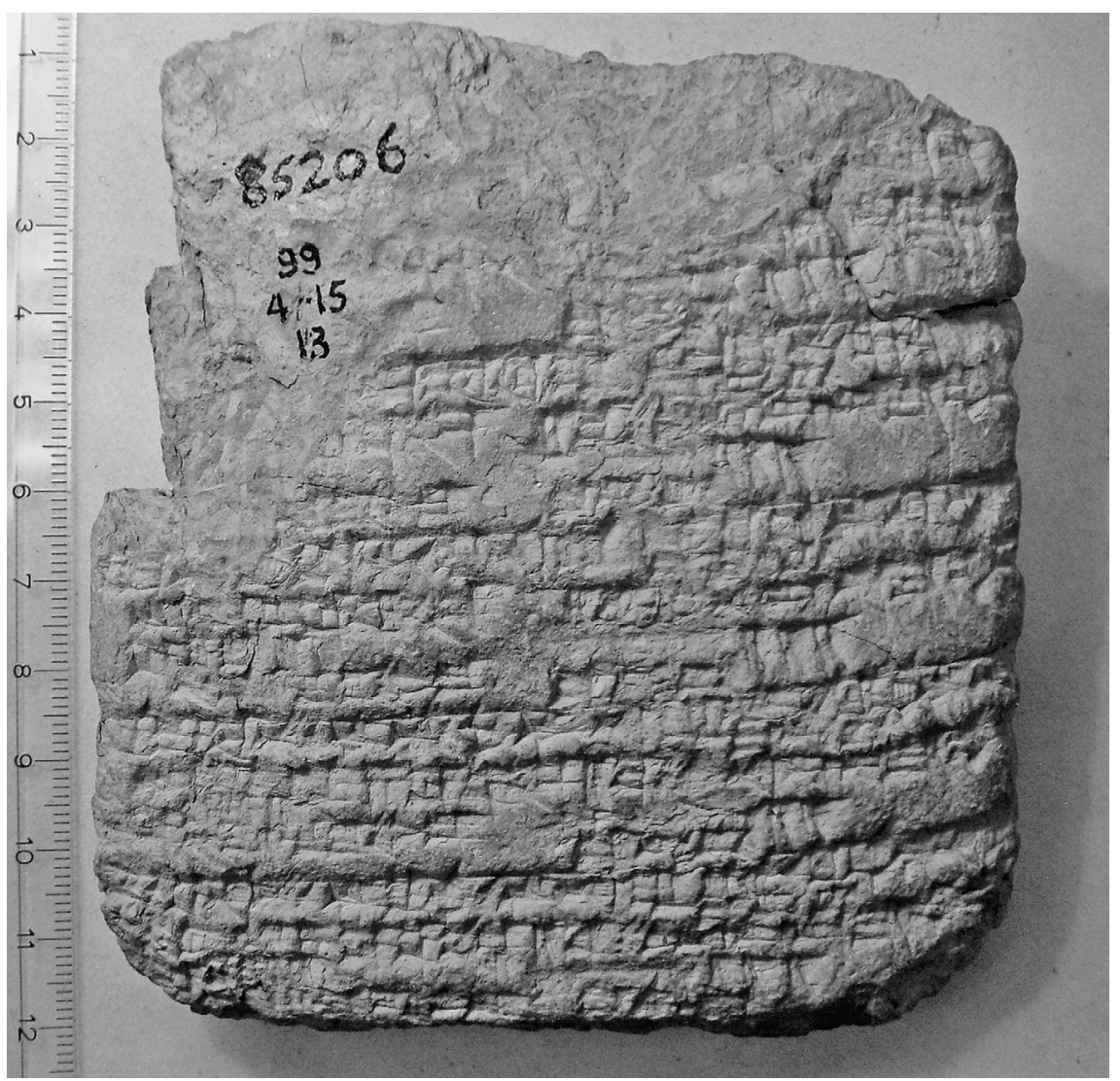

BM 85206, rev.

Rev.

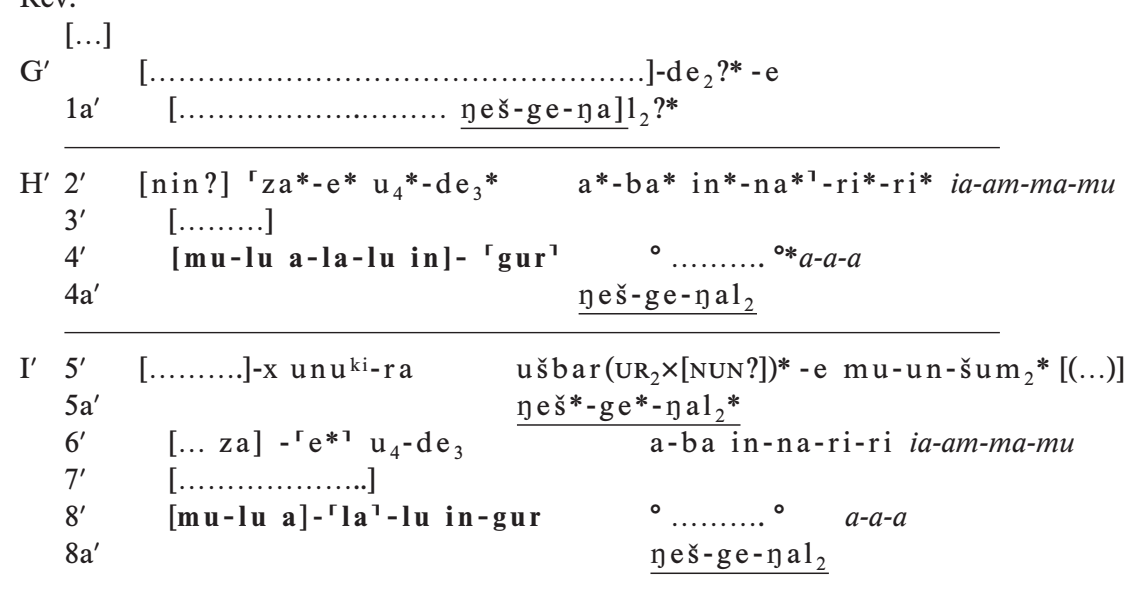




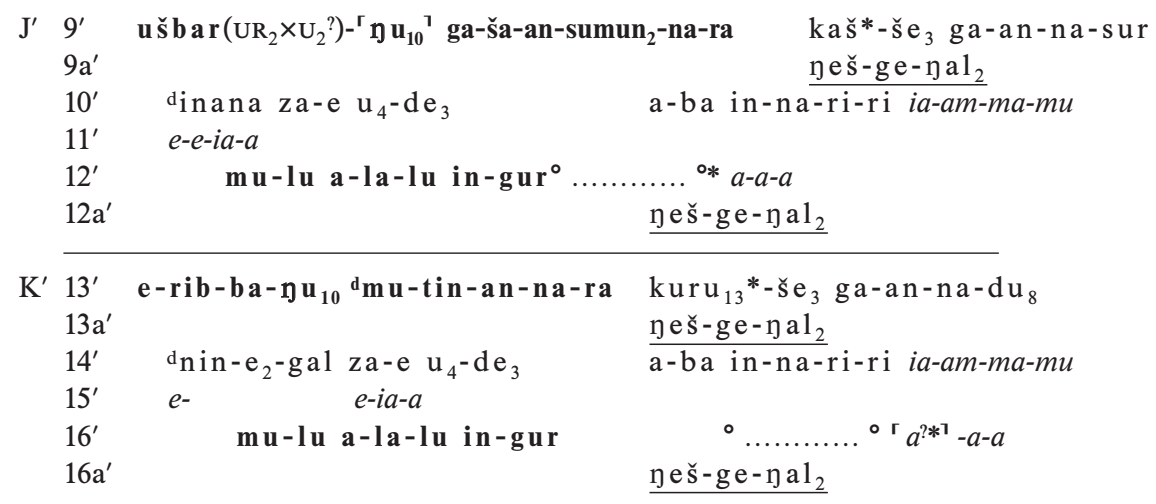

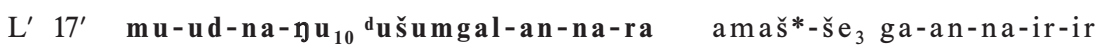

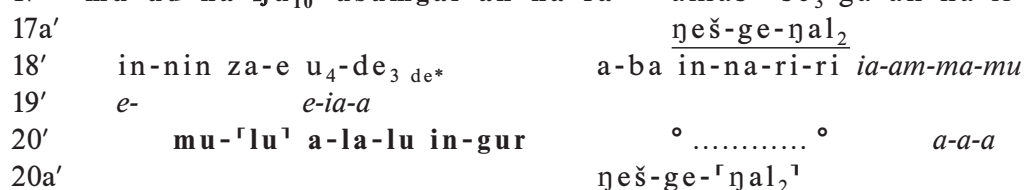

lower edge

$\mathrm{M}^{\prime} 21^{\prime} \quad\left[(\mathrm{x})\right.$ i] $a-a m-m a u_{3}-l i-l i-a[\mathrm{x}(\mathrm{x})]^{\mathrm{r}} \mathrm{x}-\mathrm{ta} ?^{?}[\ldots]$

$22^{\prime} \quad[\ldots \ldots . . .] \times$.$x nin { }^{\top}$ e? ${ }^{\top}$ A x $[\ldots]$

$23^{\prime} \quad[\ldots \ldots . ..] \times 1 i^{*} 1 i^{*}[\ldots] \times[\ldots]$

$24^{\prime} \quad \mathrm{mu} *-\mathbf{l u}$ * a-la*-lu in*-gur* $[\ldots]$

left edge

undeciphered traces

\section{Translation}

The translation indicates male and female voice, but does not note the term ye š-ge- $\mathrm{yal}_{2}$ "Response" (see the discussion below).

A (m.) [Innin] has encircled (her head) with the diadem, $u_{4} \ldots$ ladyship a...

[eya el] lu (m.) a ladyship, ladyship eyammamu

[e] $y a-a$

$a-a-a$

B (m.) Holy Inana has encircled (her head) with the diadem, $u_{4}$ ladyship $e$ ladyship $a$

eya ellu (m.) a ladyship, ladyship eyammamu

e-eya-a $a-a-a$

(f.) The man has returned the alalu-cheers!

C (m.) 'Divine Heroic ...' has encircled (her head) with the diadem, $u_{4}$ ladyship $e$ ladyship $a$

eya ellu (m.) a ladyship, ladyship eyammamu

$e-[e] y a-a \quad a-a-a$ 
(f.) The man has returned the alalu-cheers!

D (m.) [...], where the diadem encircled (her head), $u_{3}$ she was born with a crown on her head!

[...]-mu (m.) She was born with a crown on her head! yammamu

$[\ldots]$ $a-a-a$

(f.) The man has returned the alalu-cheers!

E (m.) [...], where the diadem encircled (her head), $u_{3}$ she was born with a crown on her head!

[...]-mu (m.) She was born with a crown on her head! yammamu

[...] $a-a-a$

(f.) The man has returned the alalu-cheers!

F $[\ldots] \ldots$

$\mathrm{G}^{\prime}[\ldots] \ldots$

$\mathrm{H}^{\prime}$ (m.) [Lady], you, today! Who will direct something to him? yammamu

[...] $a-a-a$

(f.) [The man has] returned [the alalu-cheers!]

$I^{\prime} \quad$ (m.) To [the ...] of Uruk, the in-law has given it.

(m.) [...], you, today! Who will direct something to her? yammamu $[\ldots]$

$a-a-a$

(f.) [The man] has returned the alalu-cheers!

$\mathrm{J}^{\prime} \quad$ (f.) For my mother-in-law Ninsumun? (m.) For beer, I will brew for her!

(m.) Inana, you, today! Who (but I) will direct something to her? yammamu

e-eya-a

$a-a-a$

(f.) The man has returned the alalu-cheers!

$\mathrm{K}^{\prime}$ (f.) For my sister-in-law Geštinana? (m.) For the granary, I will make heaps for her!

(m.) Ninegal, you, today! Who (but I) will direct something to her? уаттати

e-eya- $a$ $a-a-a$

(f.) The man has returned the alalu-cheers!

$L^{\prime} \quad$ (f.) For my husband Ušumgal-ana? (m.) For the sheepfold, I will bring him (sheep)!

(m.) Innin, you, today! Who (but I) will direct something to him? уаттати

e-eya-a

$a-a-a$

(f.) The man has returned the alalu-cheers! 


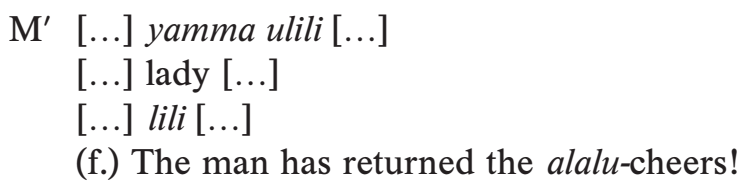

\section{Philological notes}

1 ff.: Alster $(1990,12)$ reads $m u \breve{s}_{3}$ (accepted by Fritz 2003, 158 n.636), but the sign is clearly $\mathrm{MUS}_{2}$, read $\mathrm{suku}_{5}$ (traditionally suh), a "diadem"; on this see recently Steinkeller (1998, 92-95), who describes it as "a type of band", "an object of considerable importance and value, which was worn over the head." The verb is $\mathrm{dub} / \mathrm{dab}_{6}$ "to encircle, surround"; the prefix chain nam- instead of na-an- (the ergatives require a transitive construction) was already discussed by Fritz $(2003,158$ n.636). su ku $\mathrm{dub}$ "to encircle (the head) with a diadem" is an expression for the beautiful coiffure of the bride Inana; see in this regard the discussion by Sefati (1998, 143, on Inana-Dumuzi C, see below; 317), who translates the phrase more freely as "to comb" (Sefati reads muš $\breve{2}_{2}$ instead of $\mathrm{suku}_{5} / \mathrm{suh}_{\text {). }}$.

1: The restoration [in]-nin is inspired by sequences such as the beginning of Inana and Šukaletuda (p.c. Pascal Attinger).

7 etc.: a-1a-1u describes the joyful exclamations uttered by the men in response to the women; cf. PSD A/I, 100-101 (calling it a song or an exclamation). In CT $58,15 / 16$ the men coming to Inana sing the alalu.

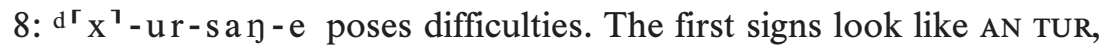
but an epithet dumu ur-san is not known as a divine name. As an epithet of Inana, dumu ur-san appears in the OB version of Uru'amairabi (Volk 1989, 35 CT 42 48:3 and and parallels; cf. CLAM p. 557 f.) du mu ur-san dmu-ul-1i1 $1_{2}-\left[1 a_{2}-m_{e} n_{3}\right]$ "I am the heroic child of Mullil (Enlil)"; for the first millennium version see Volk 1989, 136 on Tablet XX 15.

11: gur is clear on the tablet, although Alster/Geller $(1990,12)$ claim that this line "has in-du, and this is the correct reading, although in rev. 4, 5 , and 6 the sign looks like gur".

12: One could think of a restoration like $[x$ san- $-\eta] a_{2} \ldots$ "the $X$ of the head(, which was encircled by the diadem)". Here, the diadem is likened to the "crown" (men).

20: If the sign RI is correctly identified, this could point to a connection with the continuation of the text on the reverse. 
Rev. $2^{\prime}, 6^{\prime}, 10^{\prime}, 14^{\prime}$, and $18^{\prime}$ : The gloss di in rev. $18^{\prime}$ points to a reading $\mathrm{u}_{4}-\mathrm{de}_{3}$ ("on the day", $>$ "today"(?)) instead of the more frequently used $\mathrm{u}_{4}$-n e ("this day" > "today").

Rev. 5' and 9': In 5', the inscribed NUN/Ú of ušbar is not visible because of the worn surface, in $9^{\prime}$ one is inclined to see $U_{2} \times U_{2}=u$ šbar ${ }_{7}$. On the variation of the writings for the Sumerian words for the parentsin-law see Wilcke (1985, 235-238).

Rev. 9',13',17': Whereas the first halves of these lines are clearly in Emesal, the cohortative prefix ga- indicates main dialect for the latter parts. This results in a strange combination with the (incorrectly used) Emesal verb ir in 17'. Together with the performative instruction nes $\mathrm{ge}-\mathrm{nal}_{2}$ (see below) we take the use of ga- and the verb šum $\mathrm{g}_{2}$ in the preceding section (line 5', instead of Emesal $\mathrm{ze}_{2}-\mathrm{e} \mathrm{\eta}_{3}$ ) as markers of main dialect. It may be noted, however, that the cohortative prefix gamay appear very rarely in Emesal context in Old Babylonian; see Lugale 383 (van Dijk 1983, I 99, II 109f.) OB ga-an-ši-nen // SB da-ši-innen (// lullik).

Rev. 13': erib, the Sumerian term for the sister of the husband, was treated by Wilcke (1987); this is the relationship of Geštinana, Dumuzi's sister, to Inana, his bride.

\section{The Vocables}

The song CT 58, 12 features an unparalleled wealth of 'unintelligibles' or 'vocables', i.e. sonic expressions without semantic meaning. These are marked as italics in the transliteration. They include simple vocals $\left(a, e, u_{4}\right.$, $\left.u_{3}\right)$, sequences of vowels $(a-a-a)$ and syllable sequences (eya, yammamu, ellu, ulili). Such 'nonsense syllables' are sometimes called 'vocables' in musicological literature (see Nettl 1993, 114), a term that is adopted here. Vocables appear here and there in Sumerian literary texts (see below), but never to the extent of our song. However, we would not conclude that CT 58,12 is a completely unique text in this regard. More probably, vocables were written out in this instance, whereas normally they may have been added only in performance.

The Old Babylonian vocables include vowels as well as syllable sequences, which differentiates them from Late Babylonian performative notations of vowels or vowel sequences (Mirelman 2010). Furthermore, the Late Babylonian vowels add information regarding the musical performance of the text, like a musical notation. In our Old Babylonian example, the vocables can be compared to the commonly attested usage 
of exclamations of joy and lament, from a-la-la to $u_{3}-u_{8}-a$, in literary texts (see Edzard 2003, 167-170).

The scribe of CT 58, 12 has observed the following rules in the notation of the vocables: The glide $/ y a /$ is indicated by the IA sign (note $e$-ia, ia-am$\ldots$ ), so $a-a-a$ should probably not be regarded as *ayaya v.s. (thus Volk 1994, 189 n.69), but as a repeated vowel ( $\left.a^{\prime} a^{\prime} a\right)$ or as notation for an elongated single vowel $(a a a h)$. The reduplication of vowels is a relevant feature, since the text differentiates between $e-i a$ and $e-e-i a-a(1.5-6,9-10)$, the latter standing for e'eya'a or eeyaa. It cannot be excluded, however, that our text uses the IA sign only between different vowels and that sequences of identical vowels were pronounced as ayaya $(\mathrm{a}-\mathrm{a}-\mathrm{a})$ or eye $(\mathrm{e}-\mathrm{e})$, $e$-e-ia- $a$ thus representing eyeyaya.

Furthermore, the doubling of consonants is indicated (el-lu, ia-am-ma$\ldots$ against $u_{3}-l i-l i$ and $\left.-m a-m u\right)$.

Finally, $u_{4}$ and $u_{3}$ are differentiated, which may point to two vowels, perhaps o and $u$, although the differentiation is between $u_{4} / u$ and $u_{2}$ in the lexical list Proto-Aa (Westenholz 1991) and both $u_{3}$ and $u_{4}$ seem to represent /o/ (Lieberman 1979, 25).

Simple vowels: $a, e, u_{4}, u_{3}$

Simple vowels appear as exclamations within the text of main dialect Sumerian only on the obverse and only in the second half of the line or its repetition, exactly the sections marked as nešgenal (see below). Regarding the vowels, it is interesting to compare the evidence of the Late Babylonian performative notations (see Mirelman 2010): The vowel /a/ is the most widely attested, probably representing the middle pitch-range and high amplitude, /e/ is second in popularity, suggesting a middle-upper pitch-range and relatively high amplitude; the rarely attested /u/ stands for the low pitch-range and low amplitude. / $\mathrm{i} /$ is known from the LB texts but it does not appear in our text as simple vowel or in vowel(-glide) sequences.

The sequence $a-a-a$ always appears at the same point in every stanza, namely at the very right of the penultimate line. It immediately precedes the female repetitive phrase mu-lu a-la-lu in-gur „The man has returned the alalu-cheers!" Should alalu thus refer to this $a-a$ - $a$ alone, or to the complete nešgenal-response (e.g. line 2, 6, 10: $a \mathrm{nam}-\mathrm{n}$ in $\mathrm{nam}-\mathrm{n}$ in e ia-am-ma-mu, $a-a-a)$ ? As noted above, $a-a-a$ can stand for a repeated or an elongated vowel a. 
Vowel-glide sequences: $e$-e-ia- $a, e-i a$

The short eya is combined with ellu on the obverse, the long e-eya- $a$ appears both on the obverse and the reverse. ${ }^{2}$ On the obverse, the pair eya ellu, e-eya- $a$ is opposed to the single $\mathrm{nam}-\mathrm{nin}$-line in the main dialect, on the reverse e-e-ia-a is written very close to the Emesal phrase mu-lu a-la-lu in-gur; this suggests that eya ellu and e-eya-a belong to the female speech. We know of no other instances of the glide $e$-ia (eya) as an exclamation outside of this text. The alleged exclamation ya in $\mathrm{i}_{3}-\mathrm{a} 1 \mathrm{um}$ lu m (Gilgameš and Huwawa B 1 and parallels) has been interpreted as "oil-glistening one" by Marchesi (2000).

Multi-syllable vocables: el-lu, $u_{3}$-li-li, ia-am-ma-mu

For ellu, and other exclamations based on /1/, see Krecher (1966, $148 \mathrm{n}$. 433); Civil $(1976,90)$ specifically on e-el-lu as an exclamation to incite the ploughing oxen; Attinger (1993, 559); Römer (2001, 225 n. 184); and Edzard $(2003,167)$.

In our text, eya ellu obviously belongs to the female part (see above on eya). Similarly, ellu ellu-lines occur in Emesal context in CT 58 14, a song which is also related to the Dumuzi-Inana topic; and Inana repeatedly uses ellu in the "Manchester Tammuz" (lines 49, 55, 73, 75(?), and 189; Alster 1992).

The context for ulili is not well preserved $\left(1,21^{\prime}, 23^{\prime}\right.$ ?), where it appears together with yamma. On ulili see Römer (2001, $225 \mathrm{n}$. 184) and note the equation munus-ù-1i-1i = zammirtu "female singer" (Lu III = MSL 12, 124 ii 16).

Exclamations around the consonant [1] are a world-wide phenomenon, and Edzard 1.c. refers i.a. to Greek alala, Hebrew hallelüja, and, most importantly, to the ululation of the Middle East, a high-pitched vocalisation produced with an oscillating tongue from the women (and sometimes men) at emotional high points, typically at marriage ceremonies (Jacobs 2007, 489f.).

In every stanza, yammamu is attached to the end of the speech in the main dialect, and is thus a 'male' exclamation in our text. For similar exclamations in Old Babylonian Sumerian lamentations cf. Kramer (1987, 82) line 344: $i-a m_{3}-m a$ e-la-lu, closing a lament addressed to Inana; Cohen $(1988,83) \mathrm{f}+182$ : $i$-a-am-ma (context unclear); see also the similar excla-

2 This distribution excludes the reading e-ia-a proposed by Volk $(1994,189)$, who based his interpretation on the distribution of the signs on the reverse. 
mation in $\operatorname{Kramer}(1985,120)$ lines 23, 24: $a-u_{3}-a m_{3}-m a$, al-li-li-am 3 -ma in a section praising Enlil.

\section{Emesal and Main Dialect as Features of the Dialogue}

The tablet is divided in various sections (here numbered A to $\mathrm{F}$ and $\mathrm{G}^{\prime}$ to $\mathrm{M}^{\prime}$ ). The decisive clue for understanding the song's structure is provided by the sequence of phrases in Emesal (ES) and in the Main Dialect (MD) of Sumerian within each section. This clearly indicates that the text represents a dialogue between male and female participants.

The key words for the Main Dialect are: nin (instead of ES ga-šaan), nam (vs. ES na-a $\eta_{2}$ ), inana (ES ga-ša-an-an-na), šum 2 (ES $\left.\mathrm{ze}_{2}-\mathrm{en}_{3}\right)$, cohortative ga- (ES da-, $\mathrm{de}_{3}-$ ).

Emesal words are mu-lu (MD $1 u_{2}$ ), ga-ša-an (MD nin), mutin-an-na (MD neštin-an-na); mu-ud-na (MD nešdana); for the problem of the verb ir (MD tu m ${ }_{2} / \mathrm{de}_{6}$ ) see above on line 17'.

The use of pronouns underlines the distinction between male and female speech on the reverse. Inana and other goddesses are addressed in the second person (za-e/ze $4_{4}$-e) (in Rev. 2', 6', 10', 14', and 18'). On the other hand, the goddess speaks of "my husband" in Rev. 17'.

\section{Graphic arrangement}

Previous commentators have already noted the exceptional graphic arrangement of this text. Here we list the most important features:

The first line of each section starts at the left margin of the tablet, thus marking clearly the division of the text. Within the sections, lines often do not proceed uniformly from left to right. In some cases on the obverse, half lines to the left correspond to a single half line to the right (see 11. 5-6, 9-10, etc.). The vocable $a-a-a$ and the performative instruction $\mathrm{n}$ es $\mathrm{s}-\mathrm{ge}-$ $\mathrm{Dal}_{2}$ are placed in specific positions in the right half of each section. Collation of the tablet has revealed many erasures throughout the text, specifically above every instance of a section's last $\eta \mathrm{e} \breve{-}-\mathrm{ge}-\eta_{\mathrm{al}} \mathrm{l}_{2}$. This implies that the graphic displacement of the text is significant. In section D one is inclined to see erased traces of a final A, so probably the vocable $a-a-a$ was erased and later rewritten to the right of these erasures and of the $\mathrm{yes}-\mathrm{ge}-\mathrm{yal}{ }_{2}$ notation. The reason behind this correction becomes

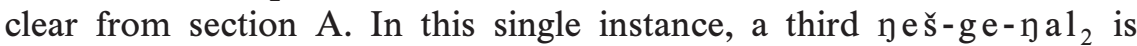
written directly underneath $a-a-a$. 
Obv.

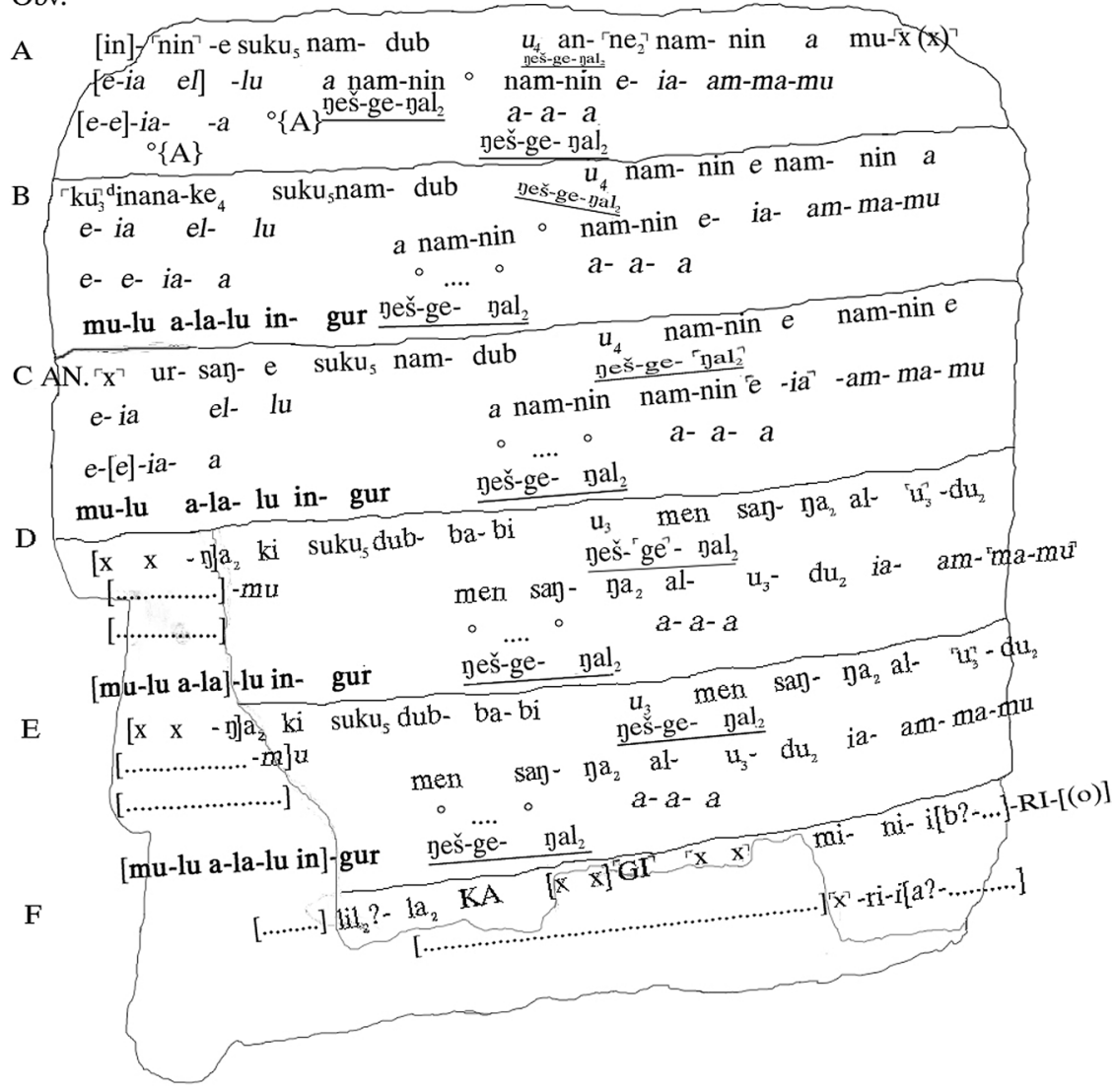

BM 85206, obv., transliteration

Throughout the text, the performative indication $\eta \mathrm{es}-\mathrm{ge}-\eta \mathrm{al} \mathrm{l}_{2}$ is written exactly below the beginning of the half lines to the right: On the obverse below the second part of the first line and below the second half line to the right; on the reverse it is written below the second part of both phrases.

This arrangement, roughly indicated in the transliteration given above, can be estimated from the illustration on theses page. This transliteration, indicating the exact spot of each sign on the tablet, was created with a photographic background image on the program Adobe Photoshop. 


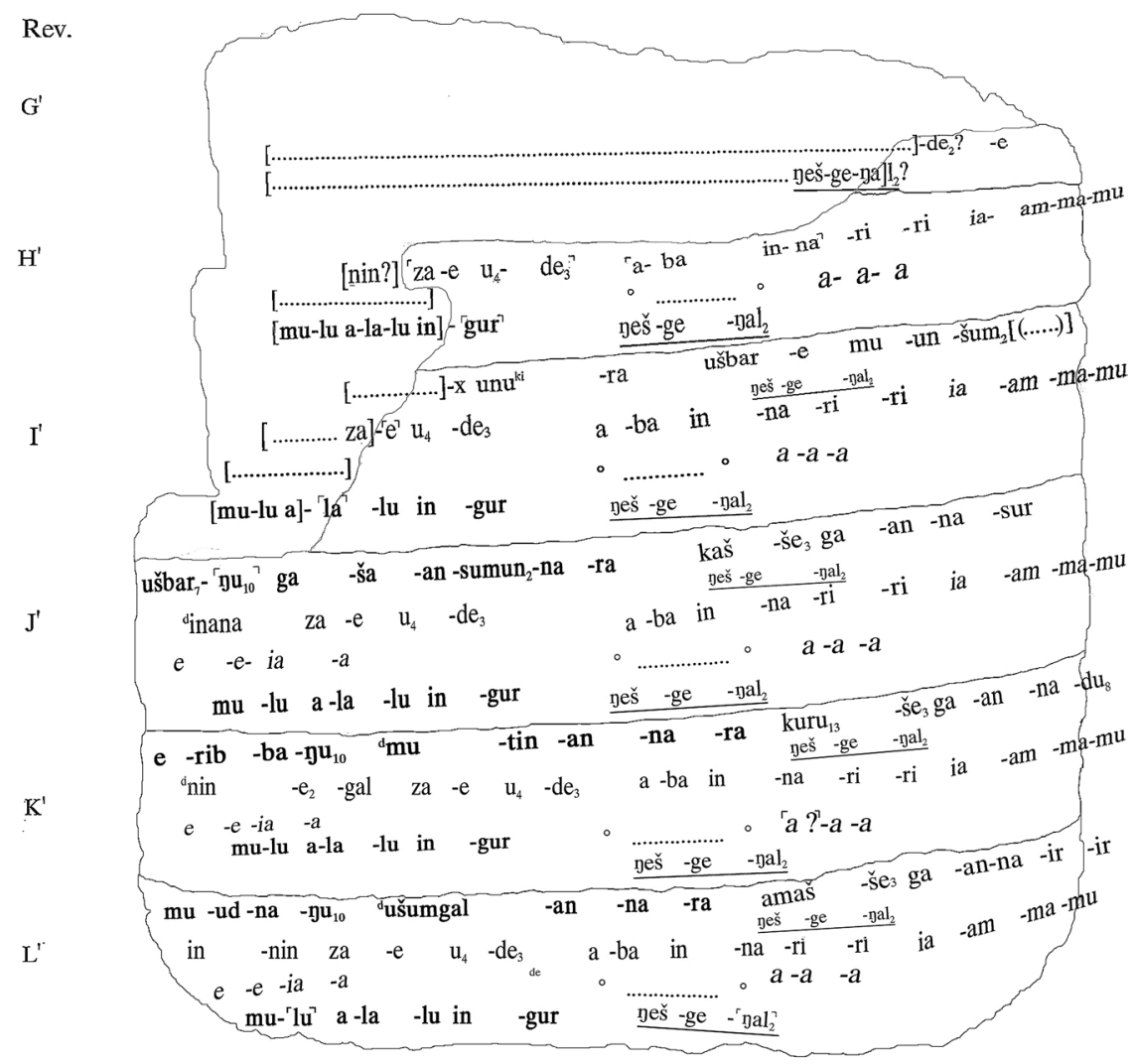

BM 85206, rev., transliteration

$$
\text { ne š-ge- } \mathrm{gal}_{2}
$$

In our text, the performative instruction $\mathrm{\eta}$ eš-ge- $\mathrm{na} 1_{2}$ marks the right half of the principal lines of each section. This unique use of the term ฤe š-ge- $\mathrm{gal}_{2}$, so well known from Old Babylonian Sumerian literary texts, demands further consideration.

The Akkadian translation of $\mathrm{n}$ es $-\mathrm{ge}_{(4)}-\mathfrak{y a l}_{2}$ as meher zamāri “answer/ response of singing" has resulted in the standard translation as "antiphone". The relevant lexical entries stem from the first millennium:

GIŠ gi-eš-gal $\mathrm{GAL}_{2}=$ MIN (mi-hir) za-ma-ri Erimhuš II 239 (MSL 17, 39) $\mathrm{mu}-\mathrm{g}[\mathrm{i}-\mathrm{ma}-\mathrm{al}]=$ ne š-gi-gal $2=$ me-eh-ru Emesal Voc. III 58 (MSL 4, 32) 


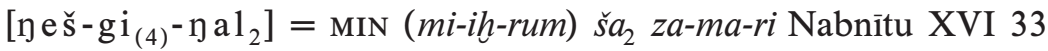
(MSL 16, 142)

In OB lexical lists, $\eta \mathrm{g} \breve{\text { s }}-\mathrm{gi} \mathrm{i}_{(4)}-\mathrm{nal} \mathrm{l}_{2}$ is only attested in OB Proto-Lu 612, 843 (MSL 12, 66 and 64).

The description of Hartmann $(1960,239-244)$ is still generally accepted: $\eta \mathrm{es}-\mathrm{ge}_{(4)}-\eta \mathrm{al}_{2}$ is used as a subscript for sections of one to four lines, usually set off from the rest of text by horizontal lines. The term always refers to a preceding section, marked as ki-ru-gu ${ }_{2}$, sa $\mathrm{gid}_{2}-\mathrm{da}$, sa-nar-ra or once as "Lament ( $\left(\mathrm{r}_{2}-\breve{s}_{3}-n e-\breve{s}_{4}\right)$ of a man's god" (Gordon 1960, 150). This can be expressed either as ne š-ge-nal -bi-(im), "(it is) its nešgenal”, or as ne š-ge- $\mathrm{gal}_{2} \mathrm{ki}-\mathrm{ru}-\mathrm{gu} \mathrm{u}_{2}-\mathrm{da}-\mathrm{kam}$ (etc.) "it is the $\mathrm{\eta}$. of a kirugu (etc.)". A similar usage is found in OB Akkadian literary texts. $^{3} \mathrm{\eta es}-\mathrm{ge}_{(4)}-\mathrm{\eta al}_{2}$-bi occurs in one OB Balay composition (CT 42, 15, pl. 28 ii 8; CLAM 194: a+38), but it is not attested in LB Emesal literary texts, where instead the Akkadian translation mehru is found (see Mirelman 2010). CT 58, 12 is the only attestation in a literary text, where the term is not qualified.

The literal meaning of the term is obscure. Wilcke $(1975,260)$ suggests "Holz zurückkehren(?) (oder: zur[?] Erde[?]) lassen", thus possibly indicating the absence of musical accompaniment. This interpretation implies that $\mathrm{n}$ es "wood" can be used as general term for "musical instrument" or short for $\mathrm{ne} \breve{s}-\mathrm{gu}_{3}$-di. However, we know of no place where $\mathrm{n}$ e $\breve{s}$ is used alone as referring to musical instruments. Two post-OB references point in other directions. Examenstext A line 8 (Sjöberg 1975, $140 \mathrm{f}$. and 151f.) equates $\eta \mathrm{es} \mathrm{ge}_{4}$ with Akkadian apālu "to answer", but subsequently the text uses the standard verb $\mathrm{ge}_{4}$ as Sumerian equivalent of apālu (lines 9 to

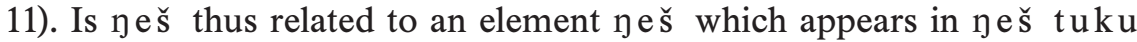
"to hear" (related to yeštu "ear") or in nešgem "sign"? For the latter possibility, the late unorthographic writing nešgem-nal $1_{2}$-bi // mi$h i[r-\check{s} u]$ (KAR 100 ii 10, bilingual hymn to Gula and Ištar) is suggestive.

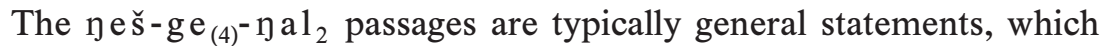
comment and summarize the single statements of the preceding text. They may be compared to the fixed part in the refrain sections of Emesal songs.

3 In Agušaya (Groneberg 1997, 55-93): ฤ e š-ge ${ }_{(4)}$ - a $_{2}$-bi (passim), Hymn to Ištar (RA 22, 171: 60, see Groneberg 1999, 169-171, translating ye š-ge- $\eta \mathrm{ll}_{2}$ as "Zusammenfassung", "Quintessenz" on p. 171 fn. 7); Hymn to Nanaya (ZA 44, 34). The Akkadian equivalent mehrum appears in a literary catalogue of late Old Babylonian or Kassite date (Finkel 1988) after 5 irtum songs, two incipits are called mehrum; Kilmer $(1992,109)$ suggests this is the antiphon of the five song incipits (or strophes according to Groneberg 2003, 58) listed above it. 
Hartmann $\left(1960,243 \mathrm{f}\right.$.) correctly notes that $\eta \mathrm{es}-\mathrm{ge}_{(4)}-\eta \mathrm{al} \mathrm{l}_{2}$ has to refer to the musical performance of the text and suggests that the ne š$\mathrm{ge}_{(4)}-\mathrm{yal}_{2}$ sections were sung by a second singer or a choir. Instead of the term "Antiphon", which has a complicated history, we prefer to use the neutral musicological terms "Call" and "Response". In this respect, the first opening part is the Call, the second the Response, whether it is a literal response or not.

The Call and Response-pattern identified by Hartmann corresponds well with CT 58,12 . Here, phrases marked as $\eta$ eš-ge- $\eta \mathrm{l}_{2}$ never start a section, but are always following an initial phrase. Furthermore, the ne š $\mathrm{ge}-\mathrm{\eta al} \mathrm{l}_{2}$ phrases appear first as verbatim repetitions in the manner of a refrain: $u_{4} / a$ nam-nin $\ldots$ in sections $\mathrm{A}, \mathrm{B}, \mathrm{C}$, men san- $\mathrm{na} \mathrm{a}_{2} \ldots$ in $\mathrm{D}$ and $\mathrm{E}, \mathrm{a}-\mathrm{b}$ a in-na-ri-ri in $\mathrm{H}^{\prime}$ to $\mathrm{L}^{\prime}$; secondly, they start expressions of a similar structure (OBJECT-š $e_{3}$ ga-an-na-VERB) in $J^{\prime}$ to $L^{\prime}$. Finally, as noted above, the vocable $a-a-a$ can also be considered a nešgenal.

To sum up, $\eta \mathrm{e} \breve{\mathrm{s}}-\mathrm{ge}-\mathrm{\eta} \mathrm{l}_{2}$ phrases appear as constant refrains or as the completion of a sentence. Whereas the ne š-ge-nal 2 phrase itself is always in the Main Dialect, it may respond to either Main Dialect or Emesal phrases. The term $\eta \mathrm{e} \breve{\text { s }} \mathrm{ge}-\mathrm{\eta a} \mathrm{l}_{2}$ thus does not refer to the dialogue between Dumuzi and Inana (or their human representatives). The first halfline shows more variation, although also some repetition is apparent here, a wide-spread feature of Sumerian literature. In general, passages marked as $\mathrm{ne} \breve{\mathrm{s}}-\mathrm{ge}-\mathrm{\eta} \mathrm{al}_{2}$ are Responses, which were most probably performed by a choir. However, it remains unknown if the enigmatic term yes s-ge- $\mathrm{yal}_{2}$ refers to the literary-musical pattern 'Response', to the choir as performer, ${ }^{4}$ or to another aspect of the performance.

\footnotetext{
4 A few references concerning choral performance in Early Mesopotamia may suffice here: The OB Mari ritual for the Balan uru'ama'irabi involves a group of musicians (šitru), nārum and kalûm singers (Ziegler 2007, 14 and 55-64); kalûšunu izammarū"they all/their kalu lamentation singers sing" in an OB Emesal text (BE 30, 12 i 24; cf. e.g. Krecher 1966, 118); gala-ze ${ }_{2}-\mathrm{e}_{3}=\bar{a} s \hat{\hat{u}}$ "solo(?) performer/kalû", gala keš $\mathrm{e}_{2}$-da = MIN (= kala?/āși?) kișri "kalû/performer of the group/choir" (Lu IV 172f., MSL 12, 134); PBS $1 / 111$ iv 84 x-me-eš te $\breve{s}_{2}$-bi $\mathrm{si}_{3}$-ke-bi-ne "they are ..., their (music) makings in harmony" // ii 52 ša rigimšunu ištēniš šuteš [mû] "(those) whose voices are together brought into accord" (translation by Westenholz 2005, 366) and other passages in the same text (Westenholz 2005); cf. also Alster (1985); Ambos (2006-2008, $501 \mathrm{f}$. “Solo-Sänger und Chor-Sänger").
} 


\section{The performance}

The preceding considerations lead to a reconstruction of the performance of the text of CT 58,12. It is reasonable to suggest that the first, more variable half-lines were performed by a male soloist or a female voice, whereas the second half-lines were sung by a (male) choir ( $\mathrm{neš}-\mathrm{ge}-\mathrm{\eta a} \mathrm{l}_{2}$, Response). This means that at least three 'parties' performed the song of CT 58, 12: a male soloist and his choir, and a female voice.

A more detailed reconstruction of the performing parts must begin with the reverse. In I' to $\mathrm{L}^{\prime}$ each section's first line shows the sequence of a female Call and a male Response, i.e. a male choir (see commentary on lines $9^{\prime}, 13^{\prime}$, and $\left.17^{\prime}\right)$. The second line (lines $\left.2^{\prime}, 6^{\prime}, 10^{\prime}, 14^{\prime}, 18^{\prime}\right)$ is a male Call and Response sequence, the latter ending in -yammamu. Although written separately, the vocable sequence $a-a-a$ must be a choral Response (according to section $\mathrm{A}$ ) which follows $e$-eya-a. e-eya- $a$ was probably sung by the female part because of the close proximity to the phrase $\mathrm{mu}-1 \mathrm{u}$ a-1u-1u in-gur (see already above). The female phrase mu-lu a-la-lu in-gur concludes each section. This results in the following reconstructed sequence (example $\mathrm{J}^{\prime}$ ):

female voice: ušbar ${ }_{7}\left(U_{2} \times U_{2}{ }^{?}\right)-{ }^{\top} \mathrm{gu}_{10}{ }^{\top}$ ga-ša-an-sumun ${ }_{2}-\mathrm{na}-\mathrm{ra}$ („For my mother-in-law Ninsumun”)

male choir: kaš-še ${ }_{3}$ ga-an-na-sur ("For beer, I will brew for her!") male soloist: dinana $\mathrm{za}-\mathrm{e} \mathrm{u}_{4}-\mathrm{de}_{3}$ "(Inana, you, today!")

male choir: a-ba in-na-ri-ri yammamu ("Who (but I) will direct something to her? yammamu")

female voice: e-eya- $a$

male choir: $a-a-a$

female voice: mu-1u a-1a-1u in-gur ("The man has returned the alalu-cheers!")

Applying this pattern to the obverse, we obtain the following structure. In A to C, a male soloist's Call is followed by a male choral Response in the first line. Since $e$-eya- $a$ is clearly female on the reverse, we regard the same sequence as female on the obverse; furthermore, the graphic arrangement indicates that the vocable sequence eya ellu belongs to the female voice (see above on ellu in the Manchester Tammuz). Considering the top to bottom and left to right sequence of writing, we propose the following reconstruction (example section $\mathrm{B}$ ):

male soloist: ${ }^{ } \mathrm{ku}_{3}{ }^{\mathrm{T}} \mathrm{dinana-ke_{4 }} \mathrm{suku}_{5} \mathrm{nam-dub}$ ("Holy Inana has encircled (her head) with the diadem") 
male choir: $u_{4}$ nam-nin $e$ nam-nin $a$ (“ $u_{4}$ ladyship $e$ ladyship $a$ ") female voice: eya ellu

male choir: $a$ nam-nin nam-nin e yammamu (" $a$ ladyship, ladyship e yammamu")

female voice: $e$-eya- $a$

male choir: $a-a-a$

female voice: mu-lu a-1a-1u in-gur ("The man has returned the alalu-cheers!")

This reconstruction is informed by the distribution of dialects, the position of the performative indication $\mathrm{nes}-\mathrm{ge}-\mathrm{\eta al} l_{2}$ and the text's graphic arrangement. Now we understand how the scribe of CT 58, 12 left important clues for the performance of this song, e.g. by placing eya ellu and $e$-eya- $a$ close to each other on the 'female side' of the tablet. The possibility must not be excluded that some female vocables were sung simultanously with the male choir parts, or that female and male vocables resounded together, but the available evidence does not point in this direction.

\section{The ceremonial context}

The main protagonists of the song CT 58, 12 are Inana and Dumuzi. In the first part of the song (obverse), the male soloist and the choir praise Inana's beauty. In the second part, the men proclaim that they will provide food, namely beer (rev. 9'), barley for bread (rev. 13') and meat from the sheepfold (rev. 17'). The food is destined for the new relatives of Inana, her mother in-law Ninsumun, her sister-in-law Geštinana, and her husband Dumuzi himself.

Our song relates to a specific moment within the larger context of the marriage of Inana and Dumuzi. In the text called "Dumuzi's wedding" (Dumuzi-Inana $C_{1}$, Sefati 1998, 286-300; Fritz 2003, 75-78) various men, called paranymphs (libirsi, i 21) and including Dumuzi himself, bestow foodstuffs to Inana. Her mother, an expert in ilu-songs (i-lu-zu, ii 3) explains that he will be like a relative. Inana bathes and dresses up to receive Dumuzi.

Similarly, in Dumuzi-Inana C (Sefati 1998, 132-150), Inana presents herself as having bathed and dressed, and finally being adorned by a diadem and jewels (cf. above on CT 58, 12: $1 \mathrm{ff}$.). At the appearance of her 'brother', Dumuzi according to Sefati's interpretation, the "musicians" (nar-e-ne) start their performance (DI C 28). Inana wishes that her bridegroom may provide her with animals.

Both Wilcke (1985, 274-279) and Greengus (1990) have pointed to the central role of a ceremonial meal in the context of marriage. The "bride- 
wealth" consists of foodstuffs destined for the meal of the bride's and the bridegroom's families. There, the bridegroom does not appear alone; he is accompanied by his paranymphs, a group of young male companions (Malul 1989).

The song CT 58, 12 fits this context precisely: The bride Inana has dressed up, and appears at the door, where she is praised by the men. They, on their side, provide food for the communal meal. The group of men, the male choir who sings the ne š-ge- $\mathrm{yal}_{2}$ passages of our reconstruction, can be identified with the paranymphs of the marriage ceremony. This is the right moment for singing and music, as it is referred to in Dumuzi-Inana C. Thus, the song preserved on the tablet CT 58, 12 was performed at a wedding ceremony: a female voice, representing the bride and (probably) her female companions, alternates with the male choir of the paranymphs, including the bridegroom. The male soloist addresses Inana and her attractive appearance, although there is no indication that the male soloist represented the bridegroom Dumuzi.

The reference to the mythological marriage of Dumuzi and Inana, the musical performance by men and women, and the correlation with marriage procedures in Early Mesopotamia all point to the actual use of this song in a wedding ceremony. The bride and the bridegroom are presented as the divine bridal couple Inana and Dumuzi. Similarly, in ancient Greek wedding songs, the names of the bride and groom are sometimes replaced by the names of gods, especially Zeus and Hera (Hague 1983, esp. 134). Furthermore, the physical features of the tablet (see Introduction) would point towards its practical use in performance.

The indicator neš-ge-nal graphic arrangement have allowed for a detailed reconstruction of the manner by which such a wedding song was performed. This singular text may thus serve as an example for the performance practice of other Sumerian songs, especially those concerned with Dumuzi and Inana.

\section{References}

Alster, B. (1985): Geštinanna as Singer and the Chorus of Uruk and Zabalam: UET 6/1, 22, JCS 37, 219-228

- (1992): The Manchester Tammuz, ASJ 14, 1-46

Alster, B./M. Geller (1990): Sumerian literary texts. CT 58. London

Ambos, C. (2006-2008): Sänger, Sängerin A. Philologisch, in: M. P. Streck (ed.), Reallexikon der Assyriologie und Vorderasiatischen Archäologie 11, 499-503

Attinger, P. (1993): Eléments de linguistique sumérienne. La construction de $\mathrm{du}_{11} / \mathrm{e} / \mathrm{di}$ «dire». OBO Sonderband. Fribourg/Göttingen

Civil, M. (1976): The Song of the Plowing Oxen, in: B. L. Eichler [e.a.] (eds.), Kramer Anniversary Volume. AOAT 25. Kevelaer [e.a.], 83-95 
Cohen, M. E. (1988): The Canonical Lamentations of Ancient Mesopotamia. Potomac, Md.

Dijk, J. J. A. van (1983): Lugal ud me-lám-bi nir-g̃ál. Le récit épique et didactique des Travaux de Ninurta, du Déluge et de la Nouvelle Création. Leiden

Edzard, D. O. (2003): Sumerian Grammar. Handbook of Oriental Studies I/71. Leiden/ Boston

Finkel, I. L. (1988): A Fragmentary Catalogue of Lovesongs, ASJ 10, 17-18

Fritz, M. M. (2003): “... und weinten um Tammuz”. Die Götter Dumuzi-Ama’ušumgal'anna und Damu. AOAT 307. Münster

Gordon, E. I. (1960): A New Look at the Wisdom of Sumer and Akkad, BiOr. 17, 122-152

Greengus, S. (1990): Bridewealth in Sumerian Sources, HUCA 51, 25-88

Groneberg, B. (1997): Lob der Ištar. Gebet und Ritual an die altbabylonische Venusgöttin. Tanatti Ishtar. Cuneiform Monographs 8. Groningen

- (1999): "Brust" (irtum)-Gesänge, in: B. Böck [e.a.] (eds.), Munuscula Mesopotamica. Festschrift für Johannes Renger. AOAT 267. Münster, 169-195

- (2003): Searching for Akkadian lyrics: From Old Babylonian to the "Liederkatalog" KAR 158, JCS 55, 55-74

Hague, R. (1983): Ancient Greek Wedding Songs: The Tradition of Praise, Journal of Folklore Research 20, 131-143

Hartmann, H. (1960): Die Musik der sumerischen Kultur. Diss. Frankfurt a. Main

Jacobs, J. E. (2007): 'Unintelligibles' in vocal performances at Middle Eastern marriage celebrations, Text \& Talk 27, 483-507

Kilmer, A. D. (1992): Musical Practice in Nippur, in: M. deJong Ellis (ed.), Nippur at the Centennial. Papers Read at the $35^{\mathrm{e}}$ Rencontre Assyriologique Internationale, Philadelphia, 1988. OPSNKF 14. Philadelphia, 101-112

Kramer, S. N. (1985): BM 23631: Bread for Enlil, Sex for Inanna, Or. 54, 117-132

- (1987): By the Rivers of Babylon: A Balag-Liturgy of Inanna, Aula Orientalis 5, 71-90

Krecher, J. (1966): Sumerische Kultlyrik. Wiesbaden

Lieberman, S. J. (1979): The phoneme /o/ in Sumerian, in: M. A. Powell/R. H. Sack (ed.), Studies in Honor of Tom B. Jones. AOAT 203. Kevelaer [e.a.], 21-28

Malul, M. (1989): Susapinnu. The Mesopotamian paranymph and his role, JESHO 32, 241-278

Marchesi, G. (2000): ì-a lullum ${ }_{\mathrm{x}}$ ù-luh-ḩa sù-sù. On the incipit of the Sumerian poem Gilgameš and Huwawa B, in: S. Graziani (ed.), Studi sul Vicino Oriente antico dedicati alla memoria di Luigi Cagni. Napoli, II 673-684

Mirelman, S. (2010): Performative Indications in Late Babylonian Texts, in: R. Pruzsinszky/D. Shehata (eds.), Musiker und ihre Rolle bei der Verschriftlichung und Tradierung von literarischen Werken. Wien, 241-264

Nettl, B. (1993): Words and Songs, Language and Music: An Enduring Issue in Ethnomusicology, in: B. C. Wade (ed.), Text, Tone and Tune: Parameters of Music in Multicultural Perspective. New Delhi e.a., 107-119

Römer, W. H. Ph. (2001): Hymnen und Klagelieder in sumerischer Sprache. AOAT 276. Münster

Sefati, Y. (1998): Love Songs in Sumerian Literature. Critical Edition of the DumuziInanna Songs. Ramat Gan

Shehata, D. (2009): Musiker und ihr vokales Repertoire. Göttinger Beiträge zum Alten Orient 3. Göttingen

Sigrist, M./R. Zadok/C. B. F. Walker (1996): Catalogue of the Babylonian Tablets in the British Museum III. London 
Sjöberg, Å. W. (1975): Der Examenstext A, ZA 64, 137-176

Steinkeller, P. (1998): Inanna's archaic symbol, in: J. Braun [e.a.] (ed.), Written on Clay and Stone. Ancient Near Eastern Studies Presented to Krysztyna Szarzyǹska [...]. Warsaw, 87-100

Volk, K. (1989): Die Balag̃-Komposition úru àm-ma-ir-ra-bi. Rekonstruktion und Bearbeitung der Tafeln 18 (19' ff.), 19, 20 und 21 der späten, kanonischen Version. Freiburger altorientalische Studien 18. Stuttgart.

- (1994): Improvisierte Musik im alten Mesopotamien?, in: W. Fähndrich (ed.), Improvisation II. Winterthur, 160-202

Westenholz, J. G. (2005): Sing a song for Šulgi, in: Y. Sefati et al. (eds.), “An Experienced Scribe Who Neglects Nothing". Ancient Near Eastern studies in Honor of Jacob Klein. Bethesda Md., 343-373

Wilcke, C. (1975): Formale Gesichtspunkte in der sumerischen Literatur, in: S. J. Lieberman (Hg.), Sumerological Studies in Honor of Thorkild Jacobsen on his Seventieth Birthday June 7, 1975. AS 20. Chicago, 205-316

- (1985): Familiengründung im Alten Babylonien, in: E. W. Müller (Hg.), Geschlechtsreife und Legitimation zur Zeugung. Veröffentlichungen des Instituts für Historische Anthropologie 3. Freiburg/München, 213-317

- (1987): Die Schwester des Ehemannes (/erib/), in: J.-M. Durand (ed.), La femme dans le Proche-Orient antique. CRAI 33. Paris, 179-187

Ziegler, N. (2007): Les musiciens et la musique d'après les archives de Mari. FM 9. Paris 